\title{
Effect of the Association of Gender and Specialization on the Relationship between Job Satisfaction and Performance in the Tax Field: Tunisian Context
}

\author{
Submitted 25/07/20, $1^{\text {st }}$ revision 28/09/20, $2^{\text {nd }}$ revision 09/12/20, accepted 20/03/21
}

\author{
Lassaad Abdelmoula ${ }^{1}$
}

\begin{abstract}
:
Purpose: The present work aimed to investigate the impact of job satisfaction on performance in keeping tax records, a comparative study between accounting and non-accounting professionals in Tunisia.

Design/methodology/approach: Our methodology was applied to two groups: the first group consisted of 121 males, including 52 accounting and 69 non-accounting professionals. The second group is composed of 104 females, including 50 accounting and 54 non-accounting professionals.

Findings: Based on the comparison between the free and constrained models, the results prove that" accounting" and "non-accounting" professionals differ significantly concerning the effect of job satisfaction on performance due to significant moderating role of specialization in the relationship between job satisfaction and job performance. Furthermore, our empirical results confirm the significant difference between the "male" and "female" participants in terms of the effect of job satisfaction on job performance. Therefore, gender has a moderating effect on the relationship between job satisfaction and performance.

Practical Implications: Tunisia has lately witnessed a rapid growth in the number of Tunisian professionals working in the tax field (the profession on tax records and bookkeeping). This not only concerns their number or gender (increasing intervention of women) but also the diversity of disciplines, training, and diplomas.

Originality/value: In this sense, accounting, or non-accounting professionals, such as tax lawyers or tax advisers, perform this tax mission. Moreover, the conflict between these professionals is becoming more and more acute, searching for legitimacy to decide on the exclusive right to undertake this type of mission.
\end{abstract}

Keywords: Accounting professionals, non-accounting professionals, gender, tax records, job satisfaction, work performance, Tunisia.

Paper type: Research paper.

\footnotetext{
${ }^{1}$ Department of Accounting, Faculty of Economics and Management of Sfax, Tunisia, lassaad.abd86@gmail.com
} 


\section{Introduction}

Taxation is becoming increasingly important in business management. Nowadays, managers increasingly actively include the tax imperative in their decision-making process. It is no longer interpreted in terms of the taxes payable but from several angles. Thus, it is a source not only of additional costs but also of annuities for the company. Managers are, therefore, in continuous search of loopholes offered by tax law to ensure better tax optimization so that they minimize the tax burden and take advantage of the available tax benefits. In this sense, better tax planning is an overriding challenge, which can provide a competitive edge. As a result, the study of the company's tax situation and tax records needs to be more refined being as optimal as possible, given the crucial role of professionals and specialists responsible for this mission. Hence the importance of the competence and performance of these professionals to meet the objectives is highly sought by the company.

The relevance and effectiveness of organizations to retain the best professional skills depend on their ability to create a favorable working environment that can positively influence professionals' attitudes and behaviors in their work. This leads to searching underlying factors behind professionals' attitudes and behaviors in their work (Chang et al., 2018). A review of the literature by Luttman et al. (2003) highlighted four main factors, namely job satisfaction, job performance, organizational commitment, and role stress. These four factors are likely to model the work environment and subsequently define the attitudes of professionals. Besides, these factors that are interrelated, we can create a causal relationship between them. In this context, we focus on the relationship between job satisfaction and performance (Saman, 2020). Besides, research into the relationship between the work environment and work attitudes has relied on moderating variables, the most widespread of them are gender and specialization.

Thus, to meet our research objective, which included a comparison between accounting and non-accounting professionals, we used a moderating variable, namely specialization, to explain job performance in the tax field (Luttman et al., 2003). We also included gender as a moderator variable to compare male and female professionals. In this work, we examined the relationship between the performance of professionals in keeping tax records and their level of satisfaction.

\section{Literature Review and Research Hypotheses}

\subsection{Relationship Between Job Satisfaction and Job Performance}

Job satisfaction has recently gained momentum not only because it is essential but also because it is associated with other work attitudes (Van Scotter, 2000; Valaei and Jiroudi, 2016).

Lambert et al. (1999) define job satisfaction as "an effective (that is emotional) reaction to one's job, resulting from an incumbent's comparison of actual outcome 
with desired (expected, deserved, etc.) outcomes" (Casuneanu et al., 2019). Similarly, Locke (1969) assumes that job satisfaction is considered as "the pleasurable emotional state resulting from the appraisal of one's job as achieving or facilitating one's job value" (Shaju and Subhashini, 2017). As a result, job satisfaction describes a professional's moral or psychological state who seems to find his desires and expectations in his work environment. This can only positively impact his professional behavior that can materialize into improved performance and efficiency (Alromaihi and Alshomaly, 2017; Ölçer and Florescu, 2018).

Several studies have found a positive relationship between job satisfaction and performance (Karatepe and Tekinkus, 2006; Babakus et al., 1999; Mohr and Puck, 2007; Rod et al., 2008; Platis et al., 2015; Ali and Qun, 2019). Similarly, Mowday et al. (1982) found that performance is associated with a high level of job satisfaction (Govender et al., 2018). However, other studies have found no significant relationship between job variables (Judge et al., 2001; Lefter et al., 2018).

Therefore, the results of previous works are mixed. Hence, it is difficult to predict the sign of the relationship between job satisfaction and performance. As a result, a more advanced study of the relationship between job satisfaction and performance, integrating two moderating variables, namely gender, and specialization, need to be conducted.

\subsubsection{Intervention of Gender in Explaining the Relationship between Satisfaction and Performance}

Several researchers have examined the relationship between job satisfaction and gender equality. However, the results are contradictory. Indeed, since the 1950s, the conclusions regarding gender differences in terms of job satisfaction have been inconsistent. While some studies have found that women are more satisfied than men (Ward and Sloane, 2000; Metle and Alali, 2018), others have found that men are more satisfied than women (Forgionne and Peters, 1982; Brinck et al., 2019). Also, some researchers have shown that the presence of these gender differences in job satisfaction depends on other factors, such as age, education, and position (Clark, 1997; Ward and Sloane, 2000; Mete and Sökmen, 2017).

In the accounting field, Luttman et al. (2003) found a significant relationship between job satisfaction and the gender of accounting professionals with tax missions (Takhtaei and Dezfully, 2013). However, it is noteworthy that most studies in this area report no significant gender differences in job satisfaction (Phelan, 1994; Mueller and Wallace, 1996), while Lynn et al. (1996) found a slight difference between the level of satisfaction of accounting professionals based on gender (Metle and Alali, 2018). In short, we note that the results are mixed, which prevents us from predicting the relationship between the performance of professionals and their level of satisfaction based on gender. Hence, our first hypothesis is as follows: 
Hypothesis 1: "The relationship between the performance of professionals and their level of satisfaction varies according to their gender".

\subsubsection{Intervention of Specialization in Explaining the Relationship between Satisfaction and Performance}

Luttman et al. (2003) stated that if the professional attitudes of the two groups of professionals are to be compared, their specialization should be included as a moderating variable, and they showed that accounting professionals perform better than non-accounting professionals in tax matters. As mentioned earlier, the present work aimed to compare the performance of accounting and non-accounting professionals in studying the tax records of companies. Therefore, specialization was integrated to explain the relationship between performance and job satisfaction without being able to predict its sign.

Thus, we formulate the following hypothesis:

Hypothesis 2: "The relationship between the performance of professionals and their level of satisfaction varies depending on whether they are accounting or nonaccounting professionals".

Figure 1. Research model

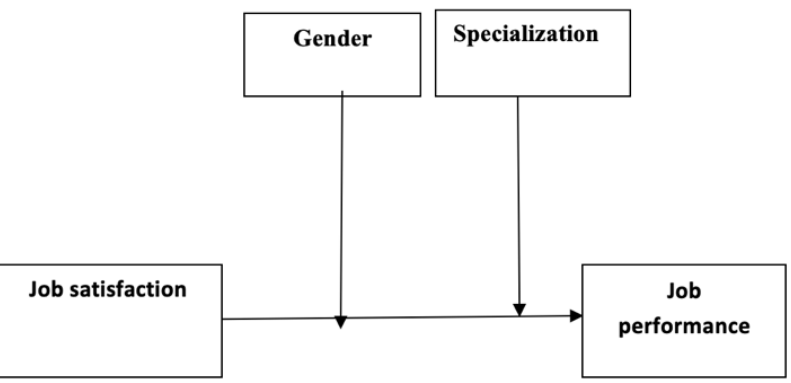

Source: Own creation.

\section{Methodology}

\subsection{Method of Data Collection}

Our sample consisted of a group of Tunisian professionals engaged in a mission to study tax records regardless of their intervention's nature, except the legal tax audit (tax assistance, tax audit, tax advice, etc.). The professionals were divided into two groups. The first was composed of accounting professionals who received training in accounting and have obtained a diploma in accounting. The second consisted of nonaccounting professionals who received tax training (tax lawyers, tax advisers, etc.). The moderating effect of gender and specialization on the results were achieved through a multi-group analysis. A two-group approach was adopted, first, the groups 
were constructed, and the accounting and non-accounting professionals in our sample were distinguished by gender and specialization. Indeed, we selected 102 out of 109 accounting professionals and 123 out of 128 non-accounting professionals. The first group consisted of 121 males, including 52 accounting and 69 non-accounting professionals. The second group is composed of 104 females, including 50 accounting and 54 non-accounting professionals.

In what follows, we will present the methodology followed to test the research hypothesis formalizing the moderating roles of "specialization" and "gender," and the main results achieved. Our objective is thus to highlight the role played by these two variables in the model. Below we present the conceptual model, the calculation steps required to highlight the moderating effects of "specialization" and "gender" in the relationship between job satisfaction and work performance. Indeed, Luttman et al. (2003) recommend transforming the moderator variable into a dummy one. Several groups of observations are to be constructed. In practice, the median is often used. The data were collected through a questionnaire administered to the professionals constituting our sample.

\subsection{Data Analysis}

Table 1 presents the research variables, their measurement the the corresponding source.

Table 1. Variables' measurement

\begin{tabular}{|c|c|c|}
\hline Variables & Measurement & Authors \\
\hline Job performance & 12 items & (Choo ,1986) \\
\hline Job satisfaction & 4 items & $\begin{array}{c}\text { (Hong and } \\
\text { Waheed, 2011) }\end{array}$ \\
\hline Gender & $\begin{array}{l}\text { Binary variable } 0 \text { : Male } \\
\text { 1: Female }\end{array}$ & (Luttman, 2003) \\
\hline Specialization & $\begin{array}{l}\text { Binary variable } 0 \text { : Accounting } \\
1 \text { : Non-accounting }\end{array}$ & (Luttman, 2003) \\
\hline
\end{tabular}

Source: Own creation.

We proceeded with the principal component analysis to reduce the number of items and determine the significance and value of the correlation between job satisfaction and job performance in each of the formed groups using multi-group analysis.

\section{Results and Discussion}

According to Baro et al. (1986), a moderator variable represents the direction and strength of the relationship between an independent variable and a dependent one. Thus, the approach consists of comparing a so-called "free" model, where the 
correlations between the latent variables are free, with the so-called "constrained" model, where the correlations are constrained to be equal to 1. Furthermore, if the calculated Chi-square statistic is much higher than the theoretical value, then the moderating effect's validity is verified. Indeed, the multi-group analyses' implementation followed the same steps to control the moderating effect of each one of the two variables in the study.

Therefore, based on the value of the median of the "gender" factor, we could form two groups of observations, the first group composed of "men" (n1=48), and the second of "women" (n2=42). Moreover, based on the value of the median of the "specialization" factor, we constructed two groups of observations, the first consisted of "accounting" (n1=59), and the second of "non-accounting" (n2=31) professionals. Next, we verified whether the correlations between the constructs and their measurement variables are different from one group to another, thus justifying the use of a constrained multi-group analysis. Finally, a multi-group analysis, whether constrained or unconstrained condition was implemented makes possible to test the moderating effects of "specialization" and "gender" on the studied relationship. Also, the effects are highlighted if there are differences in the value of the correlations between the groups.

\subsection{Result of the Exploratory Factor Analysis}

A Principal factor analysis was performed using MINITAB 17 software on the first data collection followed by another factor analysis. Moreover, the oblique rotation method was chosen since the various "job satisfaction" and "work performance" scales are not assumed to be independent.

However, before performing the principal component analysis, we first checked whether the conditions for the variables' factorization were met. With the measurement of sampling accuracy according to the Kaiser, Meyer, and Olkin (KMO) procedure, we found the following indicators: 0.847 for the "job satisfaction" variable and 0.799 for the "job performance" variable. Thus, the anti-image correlation matrix statistics are satisfactory $(\geq 0.5)$, and the Bartlett test of sphericity is significant at the threshold of 0.001 .

The screen test of Cattell and Volgelmann (1977) shows a one-factor structure for four items (Hong and Waheed, 2011), which explains about $72.6 \%$ of the variance and thus, seems satisfactory. Therefore, the results are straightforward to interpret only by the principal component analysis. The principal component analysis allowed us to reduce the number of items in the "work performance" variable from 12 to 10 (total remaining items Choo, 1986). At this stage of the analysis, we believed that reducing the number of items and a slight reformulation of the items would remedy this problem. Indeed, the "work performance" variable structure explains $79.8 \%$ of the total variance (Table 2). 
Table 2. Main Results of Principal Component Factor Analyses: Job SatisfactionWork Performance

\begin{tabular}{|c|c|c|}
\hline \multirow{9}{*}{$\begin{array}{l}\text { Job } \\
\text { Satisfaction }\end{array}$} & The constraints & The results obtained \\
\hline & Standardized data & 5-point Likert scale \\
\hline & $\begin{array}{l}\text { "Factorizable" data } \\
\rightarrow \text { Diagonal of the anti-image matrix } \geq 0.5\end{array}$ & $\begin{array}{l}\text { Satisfactory } \\
\text { coefficients }\end{array}$ \\
\hline & $\rightarrow$ "Community" between variables $\geq 0.49$ & 2 withdrawn items \\
\hline & $\rightarrow$ Low or double assignment & 0 withdrawn item \\
\hline & $\rightarrow$ Bartlett Test & $\begin{array}{l}\text { Significance at } 0.001 \\
\text { level }\end{array}$ \\
\hline & $\rightarrow$ Kaiser-Meyer-Olkin (KMO) Test $\geq 0.5$ & 0.799 \\
\hline & $\rightarrow$ Kaiser rule: Eigenvalue $\geq 1$ & 1 factor \\
\hline & $\rightarrow$ Explained variance & $79.8 \%$ \\
\hline \multirow{8}{*}{$\begin{array}{l}\text { Work } \\
\text { Performance }\end{array}$} & Standardized data & 5-point Likert scale \\
\hline & $\begin{array}{l}\text { " Factorizable" data } \\
\rightarrow \text { Diagonal of the anti-image matrix } \geq 0.5\end{array}$ & $\begin{array}{l}\text { Satisfactory } \\
\text { Coefficients }\end{array}$ \\
\hline & \multirow{2}{*}{$\begin{array}{l}\rightarrow \text { "Community" between variables } \geq 0.49 \\
\rightarrow \text { Low or double assignment }\end{array}$} & 2 withdrawn items \\
\hline & & 0 withdrawn item \\
\hline & $\rightarrow$ Bartlett Test & $\begin{array}{l}\text { Significance at } 0.001 \\
\text { level }\end{array}$ \\
\hline & $\rightarrow$ Kaiser-Meyer-Olkin (KMO) Test $\geq 0.5$ & 0.847 \\
\hline & $\rightarrow$ Kaiser rule: Eigenvalue $\geq 1$ & 1 factor \\
\hline & $\rightarrow$ Explained Variance & $72.6 \%$ \\
\hline
\end{tabular}

Source: Own creation.

\subsection{Result of the Multigroup Analysis}

\subsubsection{The Moderating Role of the Variable "Gender"}

As part of the hypothesis (H1), and by the results obtained so far, we tested only the moderating effect of "gender" on the relationship between "job satisfaction" and "work performance." However, before testing this hypothesis, we wanted to verify whether the correlations between the constructs and their measurement variables are significantly different between the groups hence, the need for a constrained multigroup analysis. Indeed, the Chi-square statistics difference calculated is significant, and the correlation between the constituted groups is significantly different between the groups. Therefore, we can conclude that "gender" is a moderator variable, which implies that hypothesis (H1) is validated (Table 3).

Thus, thanks to the multi-group analyses, the moderating effect of "gender", as illustrated in Table 3, shows the presence of the moderating effect of accounting professional' gender on the results. Indeed, the correlation between the two genders (at the structure level) differs significantly from one group to another. Therefore, our results ensure that the relationship between job satisfaction and work performance is well moderated by gender. Moreover, the results show that the calculated chi-square 
statistics difference is well above the critical value $\left(\Delta \mathrm{chi}^{2}=46 \mathrm{vs}\right.$. $\left.\mathrm{ddl}=13\right)$. Indeed, these results show that the variable "gender" has a moderating effect since the regression on job performance has an adjusted $\mathrm{R}^{2}$ of $0.89(\mathrm{p}<0.001)$. Furthermore, the difference between the models suggests that the indirect influence of "gender" is significant. The calculated chi-square statistics difference indicates that the impact of job satisfaction on performance in keeping tax records is more important for the male $(\gamma=0.639)$ than the female $(\gamma=0.455)$.

Table 3. Validation of hypothesis $H 1$

\begin{tabular}{|c|c|}
\hline Choice of a type of analysis & Moderating effect \\
\hline $\begin{array}{l}\text { Free measurement: } \\
\text { Chi-square }=124(\mathrm{ddl}=76) \\
\text { Constrained model: } \\
\text { Chi-square }=78(\mathrm{dd}=89) \\
\text { Chi-square difference: } \\
\Delta \text { Chi-square }=46(\Delta \mathrm{ddl}=13) \\
\rightarrow \text { Significant } \\
\text { Chi-square difference of } \\
(\mathrm{p}<0.04) \text { : constraint analysis }\end{array}$ & 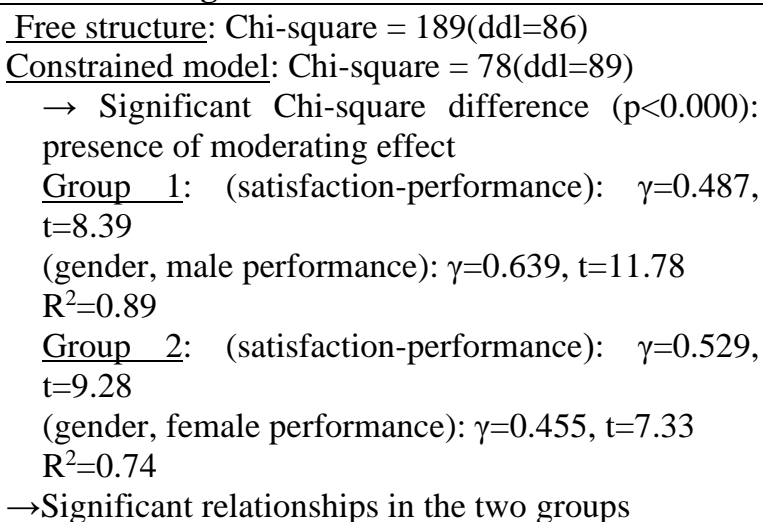 \\
\hline
\end{tabular}

Source: Own creation.

\subsubsection{The Moderating Role of the "Specialization" Variable}

We want to ensure that the relationship between job satisfaction and job performance is well moderated by specialization. Indeed, the results show that the calculated chisquare statistics difference is much higher than the theoretical value $(\Delta$ chi-square $=35$ vs. ddl=36). Furthermore, by the remarks of Luttman et al. (2003) and this first result, we consider "specialization" as a moderating variable of the relationship between job satisfaction and work performance in our model.

The strength of the relationship between job satisfaction and job performance is affected by specialization. The calculated Chi-square statistics difference is significant (Williams and Brown, 1994). Therefore, the correlation between the formed groups (at the structure level) differs significantly from one group to another. The calculated chi-square statistics difference indicates that the relationship between job satisfaction and performance in keeping tax records is more important for the accounting professionals $(\gamma=0.714)$ than the non -accounting professionals $(\gamma=0.591)$. Furthermore, the regression on work performance has an adjusted $\mathrm{R}^{2}$ of 0.66 $(\mathrm{p}<0.001)$, which means that hypothesis $(\mathrm{H} 2)$ is validated (Table 4$)$.

Thus, in accordance with this first result, we consider "specialization" as a moderating variable in the relationships between satisfaction and work performance in our model. 
Table 4. Validation of hypothesis $H 2$

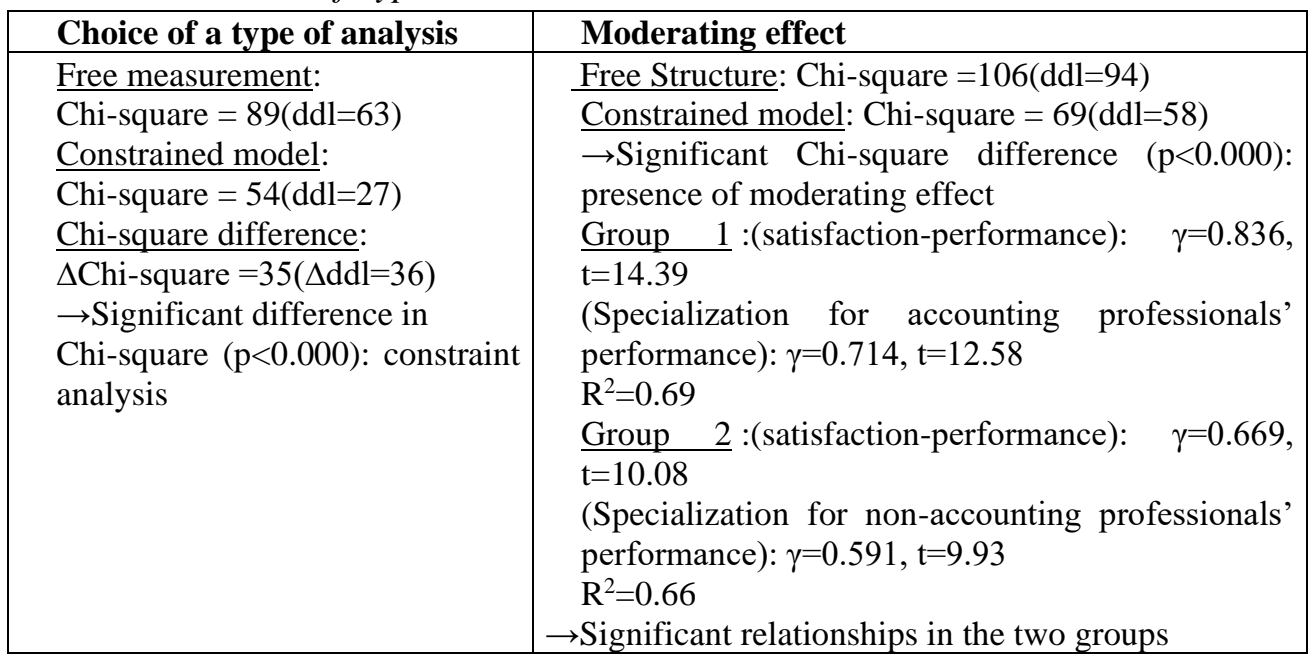

Source: Own creation.

\section{Conclusion}

The present work aimed to examine the effect of the association gender and specialization on the relationship between job satisfaction and performance of professionals in keeping tax records. The first hypothesis on the relationship between the performance of professionals in keeping tax records and their level of satisfaction varies according to their gender. The second hypothesis on the relationship between the performance of professionals and their level of satisfaction varies depending on whether they are accounting or non-accounting professionals.

We chose the multi-group approach to study the moderating role of gender and specialization in the relationship between job satisfaction and work performance in keeping tax records. Given the validation of the two hypotheses, it seems relevant to explain the relationship between job satisfaction and tax records' performance by the moderating effect of gender and specialization. Our results show the importance of these two variables as there is a significant difference between "accounting" and "non-accounting" professionals and between "male" and "female" professionals regarding the effect of job satisfaction on work performance in keeping tax records.

\section{References:}

Ali, M., Qun, W. 2019. Factors Contributing to Job Satisfaction and Job Performance of Nurses in the Healthcare Industry. International Journal of Humanities and Social Development Research, 3(1), 7-22.

Alromaihi, Z.A. 2017. Job satisfaction and employee performance: a theoretical review of the relationship between the two variables. International Journal of Advanced Research in Management and Social Sciences, 6(1), 1-20. 
Babacus, E., Cavens, D.W., Johuston, M., Moncrief, W. 1999. The role of emotional exhaustion in sales force attitudes and behavior relationship. Journal of the Academy of Marketing Science, 27, 58-70.

Baro, R.M., Kenny, D.A. 1986. The moderator-mediator variable. Distinction in social psychological research.

Brinck, K., Otten, S., Hauff, S. 2019. High-Performance Work Practices and Job Satisfaction: Gender's Moderating Role. European Management Review, 16(2).

Casuneanu, I., Lefter, V., Davidescu, A.A.M. 2019. Does Company Size Matter? An Empirical Investigation on Job Satisfaction and Work Flexibility based on Romanian Employees' Opinions. International Journal of Academic Research in Business and Social Sciences, 9, 362-382.

Chang, R.D., Zuo, J. Zhao, Z.Y., Soebarto, V., Lu, Y., Zillante, G., Gan, X.L. 2018. Sustainability attitude and performance of construction enterprises: A China study. Journal of Cleaner Production, 172, 1440-1451.

Clark, A.E. 1997. Job satisfaction and gender: why are women so happy at work? Labour Economics, 4, 341-372.

Cattell, R.B., Vogelman, S. 1977. A comprehensive trial of the scree and KG criteria for determining the number of factors. Multivariate Behavioral Research, 12, 289325. http://dx.doi.or/0.120/15327906mbr1203_2.

Choo, F. 1986. Job stress, job-performance, and auditor personality-characteristics. Auditing-A Journal of Practice \& Theory, 5(2), 17-34.

Forgionne, G.A., Peeters, V.E. 1982. Differences in job motivation and satisfaction among female and male managers. Human Relations, 35, 101-118.

Govender, L., Migiro, S.O., Kyule, A.K. 2018. Flexible Work Arrangements, Job Satisfaction and Performance. Journal of Economic Behavioural Studies, 10, 268-277.

Hong, T., Waheed, A. 2011. Herzberg's motivation-hygiene theory and job satisfaction in the Malaysian retail sector: the mediating effect of love of money. Asian Academy of Management Journal, 16(1), 73-94.

Joreskog, K.G. 1971. Statistical analysis of sets of congeneric tests. Psychometrika, 36, 102133.

Judge, T.A., Thoresen, C.J., Bono, E.J., Patton, K.J. 2001. The Job Satisfaction - Job Performance Relationship: A Qualitative and Quantitative review. Psychological Bulletin, 127(3), 376-407.

Karatepe, O., Tekinkus, M. 2006. The effect of work family conflict emotional exhaustion, and intrinsic motivation on job outcomes of fort-line employees. International Journal of Bank Marketing, 24(3), 173-193.

Lambert, E., Barton, S., Hogan, N. 1999. The missing link between job satisfaction and correctional staff behaviour: The issue of organizational commitment. American Journal of Criminal Justice, 24,95-116.

Lefter, V., Casuneanu, I., Enache, A.O. 2018. Analyzing the Link Between Work Flexibility, Job Satisfaction and Job Performance Among Romanian Employees. Ovidius Univ. Annals Economic Science Series, 18, 477-482.

Locke, E.A. 1969. What is job satisfaction? Organizational behavior and human performance, 4, 309-336.

Luttman, S., Mittermaier, L., Rebele, J. 2003. The association of career stage and gender with tax accountants' work attitudes and behaviours. Advances in Taxation, 15, 111-143. 
Lynn, S.A, Cao, L.T., Horn, B.C. 1996. The influence of career stage on the work attitudes of male and female accounting professionals. Journal of Organizational Behaviour, 17, 135-140.

Mahr, A.T., Puck, J.F. 2007. Role conflict, general manager, job satisfaction and stress and the performance of IJVS. European Management Journal, 25, 25-35.

Mete, E.S., Sökmen, A. 2017. Exploring the Relationship between Job Satisfaction and Turnover Intention among Employees in Hospitality Industry: The Moderating Role of Gender. International Review of Management and Business Research, 6(3), 1287-1298.

Metle, M., Alali, A.A. 2018. Gender disparity and its impact on job satisfaction: a comparative field study. Business Studies Journal, 10(1), 1-13.

Mowday, R., Porter, L., Steers, R. 1982. Employee - Organization Linkages: The Psychology of Commitment, Absenteeism, and Turnover. Academic Press, New York.

Mueller, C.W., Wallace, J.E. 1996. Justice and the paradox of the contented female worker. Social Psychology Quarterly, 59, 338-349.

Ölçer, F., Florescu, M.S. 2018. Mediating effect of job satisfaction in the relationship between psychological empowerment and job performance. Business Management Excellence, 5, 5-32.

Phelan, J. 1994. The Paradox of the Contented Female Worker: An Assessment of Altemative Explanations. Social Psychology Quarterly, 57, 95-107.

Platis, C., Reklitisb, P., Zimerasc, S. 2015. Relation between job satisfaction and job performance in healthcare services. International Conference on Strategic Innovative Marketing, IC-SIM 2014, September 1-4, 2014, Madrid, Spain. Procedia Science Direct-Social and Behavioral Sciences, 175, 480-487.

Rod, M., Ashill, N.J., Carruthers, J. 2008. The relationship between job demand stressors, service recovery performance and job outcomes in a state-owned enterprise. Journal of Retailing and Consumer services, 15, 22-31.

Saman, A. 2020. Effect of compensation on employee satisfaction and employee performance. International Journal of Economics, Business and Accounting Research, 4(1), 185-190.

Shaju, M., Subhashini, D. 2017. A study on the impact of Job Satisfaction on Job Performance of Employees working in Automobile Industry, Punjab, India. Journal of Management Research, 9(1), 117-130.

Takhtaei, N., Dezfully, L.A. 2013. Impact of Gender upon the Perception and Auditor's Job Satisfaction. International Journal of Accounting and Financial Reporting, 3(1), 258-267.

Valaei, N., Jiroudi, S. 2016. Job satisfaction and job performance in the media industry: A synergistic application of partial least squares path modeling. Asia Pacific Journal of Marketing and Logistics, 28(5), 984-1014.

Van scotter, J.R. 2000. Relationships of task performance and contextual performance with turnover, job satisfaction and affective commitment. Human Resource Management Review, 10, 79-95.

Ward, M.E., Sloane, P.J. 2000. Non-pecuniary Advantages Versus Pecuniary Disadvantages: Job Satisfaction Among Male and Female Academics in Scottish Universities. Scottish, Journal of Political Economy, 47, 273-303.

Williams, L. Brown, B. 1994. Method variance in organizational behavior and human resources research: Effects on correlations path coefficients and hypothesis testing. New York. 